\title{
KLASIFIKASI TINGKAT KEMATANGAN BUAH KOPI BERDASARKAN DETEKSI WARNA MENGGUNAKAN METODE KNN DAN PCA
}

\author{
Siti Raysyah ${ }^{1}$, Veri Arinal ${ }^{2}$, Dadang Iskandar Mulyana ${ }^{3}$ \\ ${ }^{1,23}$ Program Studi Sistem Informasi Sekolah Tinggi Ilmu Komputer Cipta Karya Informatika \\ Jalan. Raden Inten II A No.84, Duren Sawit, Jakarta Timur - DKI Jakarta \\ 1alannur45@gmail.com \\ 2 veriarinal@yahoo.com \\ ${ }^{3}$ mahvin2012@gmail.com
}

\begin{abstract}
Abstrak - Kopi merupakan salah satu produk tanaman dibidang perkebunan yang dibutuhkan oleh masyarakat di dunia . Di Indonesia kopi termasuk komoditas ekspor yang cukup tinggi. Perkebunan kopi di Indonesia memiliki peran penting dalam perekonomian di Indonesia, serta menjadi penyedia lapangan pekerjaan bagi masyarakat sekitarnya. Kondisi dari sektor perkebunan kopi yang dibahas saat ini adalah untuk penentuan panen buah kopi berdasarkan warna kulit buah, kematangan buah kopi dimulai dari mentah, cukup matang dan matang sehingga warna dari buah kopi dapat menjadi indikator penting untuk dapat mengetahui tingkat kematangan dan kualitas buah kopi. Oleh karena itu peneliti ingin mengajukan sebuah ide untuk menjawab permasalahan pada penentuan kematangan buah kopi yang sebagian besar masih dilakukan secara manual memiliki beberapa kelemahan dan membutuhkan proses yang cukup lama, memiliki akurasi yang rendah dan tidak konsisten, hal itu dikarenakan penentuan yang dilakukan secara subjektif oleh para petani kopi. Berdasarkan permasalahan tersebut dibuatlah sebuah sistem untuk mengklasifikasikan tingkat kematangan buah kopi dengan memanfaatkan fitur warna RGB dan HSV menggunakan metode $K$-Nearest Neighbor (KNN). Klasifikasi menggunakan pengolahan citra dengan memanfaatkan software MATLAB untuk pembuatan sistem klasifikasi dengan 3 kelas yaitu mentah, cukup matang, dan matang. Dalam penelitian ini menggunakan data yang didapat dari dataset public dengan mengunduh (download) gambar terkait dari google image yaitu berupa gambar citra buah kopi yang ada pada variabel penelitian ini . Data yang digunakan dalam penelitian ini sebanyak 135 dataset yang dibagi menjadi 90 data latih dan 45 data uji. Data tersebut diklasifikasikan menggunakan metode KNN dengan mengukur jarak tetangga terdekat dengan nilai $\mathrm{K}=3$. Dari penelitian ini didapatkan hasil akurasi sebesar $97,77 \%$ dengan hasil klasifikasi data uji sebanyak 44 data mendapat hasil klasifikasi akurat dan 1 data mendapat hasil klasifikasi tidak akurat.
\end{abstract}

Kata kunci : Kopi, K-Nearest Neighbor, RGB, HSV, MATLAB

\section{Pendahuluan}

Kopi merupakan salah satu produk tanaman dibidang perkebunan yang dibutuhkan oleh masyarakat di seluruh dunia . Di Indonesia kopi termasuk komoditas ekspor yang cukup tinggi. Indonesia menempati posisi ke empat dalam ekspor dan produsen kopi di seluruh dunia, setelah Brazil, Colombia, dan Vietnam. Di indonesia sendiri ada beberapa jenis kopi, diantaranya yang banyak ditanam oleh masyarakat Indonesia adalah jenis kopi arabika dan kopi robusta[1]

Penelitian ini berkaitan dengan kondisi dari sektor perkebunan kopi saat ini yang sering diangkat menjadi topik pembahasan, misalnya dalam hal penentuan kopi berdasarkan umur buah masih dinilai kurang praktis, dikarenakan perbedaan umur antara satu buah dengan buah lainya.
Penentuan panen juga bisa ditentukan dari berubahnya warna kulit buah, keras kulit buah, rontoknya buah, dan kulit buah yang pecah untuk menentukan tingkat kematangan buah, dan pendistribusian buah kopi diberbagai macam daerah menjadikan pentingnya dalam melakukan klasifikasi buah kopi berdasarkan tingkat kematangannya. Kematangan buah kopi dimulai dari mentah, cukup matang dan matang sehingga warna dari kopi dapat menjadi indikator penting untuk dapat mengetahui tingkat kematangan buah dan kualitas buah kopi[1]

Penggolongan kematangan buah kopi bertujuan untuk mengurangi adanya resiko dari buah kopi yang masih mentah. Penggolongan kematangan buah kopi yang dilakukan secara manual masih memiliki beberapa kelemahan dan membutuhkan proses yang cukup lama, memiliki akurasi yang rendah dan serta tidak konsisten, hal itu dikarenakan 
penentuan yang dilakukan secara subjektif oleh petani kopi. Adapun penggolongan tingkat kematangan buah kopi secara otomatis, dapat lebih cepat dengan penetuan secara objektif. Selain itu dapat meningkatkan akurasi dan lebih efisien[2]

Penelitian oleh Eko Hari Rachmawanto, dan Abu Salam (2019) dengan judul " Pengukuran Tingkat Kematangan Kopi Robusta Menggunakan Metode K-Nearest Neighbour". Pada penelitian ini peneliti menggunakan metode $K$-Nearest Neighbor untuk pengklasifikasian kematangan buah kopi menggunakan algoritma K-NN. Penggunaan fitur HSV dan KNN telah diuji coba dan mendapatkan hasil akurasi tertinggi pada $\mathrm{K}=1$ sebesar $93,33 \%$ dan $\mathrm{K}=3$ sebesar 96,67\%[1]

Penelitian oleh Cinantya Paramita, Eko Hari Rachmawanto, Christy Atika Sari, dan De Rosal Ignatius Moses Setiadi (2019) dengan judul "Klasifikasi Jeruk Nipis Terhadap Tingkat Kematangan Buah Berdasarkan Fitur Warna Menggunakan $K$ Nearest Neighbor" Pada penelitian ini peneliti menggunakan metode K-Nearest Neighbor dengan hasil klasifikasi jeruk nipis dari tingkat kematangannya menggunakan fitur warna $\mathrm{k}$ yakni $\mathrm{k}=3$, dengan mengunakan $\mathrm{k}=7$ dan $\mathrm{k}=3$ pada pencarian jarak Euclidean distance yang menghasilkan akurasi sebesar 92\%[3]

Penelitian oleh Abdullah dan Pahrianto (2017) dengan judul "Sistem Klasifikasi Kematangan Tomat Berdasarkan Warna Dan Bentuk Menggunakan Metode Support Vector Machine (SVM)". Pada penelitian ini peneliti menggunakan metode Support Vector Machine (SVM) dengan hasil pengujian didapatkan bahwa sistem ini mampu memberikan akurasi rata-rata $82.83 \%$ dan simpangan baku 1.52 [4]

Penelitian oleh Muchammad Arief (2019) dengan judul "Klasifikasi Kematangan Buah Jeruk Berdasarkan Fitur Warna Menggunakan Metode SVM". Pada Penelitian ini peneliti menggunakan metode SVM dengan hasil buah tersebut sudah matang atau masih mentah. Dari hasil penelitian diperoleh akurasi kecocokan dengan presentase $80 \%$ dari data sebanyak 100 citra jeruk[2]

Penelitian oleh Dian Novianto dan Tri Sugihartono (2020) dengan judul "Sistem Deteksi Kualitas Buah Jambu Air Berdasarkan Warna Kulit Menggunakan Algoritma Principal Component Analysis (PCA) dan K-Nearest Neighbor (K-NN)". Pada penelitian ini peneliti menggunakan Algoritma Principal Component Analysis (PCA) dan K-Nearest Neighbor (K-NN) dengan hasil dari sistem ini adalah sistem mampu menghasilkan keluaran berupa pengklasifikasian kualitas dari buah jambu air secara otomatis[5]

Penelitian oleh Duwen Imantata Muhammad, Ermatita, Noor Falih (2021) dengan judul "Penggunaan K-Nearest Neighbor (KNN) untuk Mengklasifikasi Citra Belimbing Berdasarkan Fitur Warna" Penelitian ini peneliti menggunakan metode K-Nearest Neighbor (KNN) dengan hasil menggunakan algoritma KNN didapatkan akurasi sebesar $93.33 \%$ pada percobaan dengan menggunakan nilai $\mathrm{K}=7[6]$

Penelitian oleh Dinda Rizki Taningrum, Dr.Ir Bambang Hidayat IPM,Yuli Sun Hariyani S.T., M.T. (2016) dengan judul "Sistem Pengidentifikasian Plat Kendaraan Mobil Menggunakan Principal Component Analysis dan Klasifikasi KNN" Penelitian ini peneliti menggunakan metode K-Nearest Neighbor (KNN) dengan hasil sistem ini mampu mengenali 44 letak plat data uji dengan akurasi 97.78\%, akurasi segmentasi karakter sebesar $99.10 \%$ atau didapatkan dari 331 karakter yang berhasil tersegmentasi dari 334 karakter yang tersegmentasi, akurasi klasifikasi sebesar $88.92 \%$ didapatkan dari 297 karakter yang diklasifikasikan dengan benar dari 334 karakter, akurasi keseluruhan sistem sebesar $60.00 \%$ atau 27 data yang berhasil dideteksi dan diidentifikasi dari 45 data uji[7]

Penelitian oleh Yusuf Eka Yana, Nur Nafi'iyah (2021) dengan judul "Klasifikasi Jenis Pisang Berdasarkan Fitur Warna, Tekstur, Bentuk Citra Menggunakan SVM dan KNN" Penelitian ini peneliti menggunakan metode SVM dan KNN dengan Hasil ujicoba menunjukkan algoritma SVM nilai akurasi mengklasifikasi jenis Pisang secara berturut-turut dari fitur warna, tekstur, bentuk adalah 41,67\%, 33,3\%, 8,3\%. Dan hasil klasifikasi jenis Pisang dengan algoritma $\mathrm{KNN}$, nilai $\mathrm{K}$ terbaik adalah 2 pada fitur warna 55,95\%, fitur tekstur 58,33\%, dan fitur bentuk 45,24\%[8]

Penelitian oleh Anita Sindar M. Sinaga (2020) dengan judul "Implementasi Teknik Thresholding Pada Segementasi Citra Digital" Pada penelitian ini, peneliti mendapatkan hasil metode segmentasi mengasumsikan setiap objek cenderung memiliki warna yang homogen dan terletak pada kisaran keabuan tertentu. Setiap komponen warna menggunakan 8 bit (nilainya berkisar antara 0 sampai dengan 255). Proses thresholding mengkonversi citra warna menjadi hitam dan putih sehingga mempermudah mendeteksi objek[9]

Berdasarkan permasalahan dan penelitian sebelumnya yang terkait sehingga muncul ide untuk melakukan penelitian mengenai klasifikasi kematangan buah kopi menggunakan algoritma Principal Component Analysis (PCA) dan $K$ Nearest Neighbor (K-NN). Dengan adanya penelitian ini diharapkan selain untuk membantu para petani kopi, terdapat juga pengklasifikasian buah kopi yang dijual ke masyarakat sehingga kualitas kopi yang diterima oleh masyarakat menjadi lebih baik berdasarkan tingkat kematanganya.

\section{A. Klasifikasi}

Klasifikasi merupakan suatu proses untuk menemukan sekumpulan model maupun fungsi yang menjelaskan dan membedakan data kedalam kelas-kelas tertentu, dengan tujuan menggunakan model tersebut dalam menentukan kelas dari suatu objek yang belum diketahui kelasnya. Ada 2 proses dalam klasifikasi, yaitu Proses learning/training Melakukan pembangunan model menggunakan data training. Proses testing Melakukan tes terhadap data testing menggunakan model yang telah diperoleh dari proses training [10]

\section{B. Pengolahan Citra Digital}

Pengolahan citra digital adalah salah satu bentuk pemrosesan informasi dengan inputan berupa citra (image) 
dan keluaran yang juga berupa citra atau dapat juga bagian dari citra tersebut. Tujuan dari pemrosesan ini adalah memperbaiki kualitas citra agar mudah diinterpretasi oleh manusia atau mesin komputer[11]

\section{K-Nearest Neighbor}

Algoritma K-Nearest Neighbor (KNN) merupakan sebuah metode untuk melakukan klasifikasi terhadap objek berdasarkan data pembelajaran yang jaraknya paling dekat dengan objek tersebut. K-Nearest Neighbor berdasarkan konsep 'learning by analogy'. Data learning dideskripsikan dengan atribut numerik n-dimensi. Tiap data learning merepresentasikan sebuah titik, yang ditandai dengan c, dalam ruang n-dimensi[12]

\section{Principal Component Analysis (PCA)}

Principal Component Analysis adalah suatu metode untuk mengidentifikasi pola dalam suatu data dan juga untuk menonjolkan adanya perbedaan ataupun kesamaan di dalam suatu kumpulan data. Metode ini biasa digunakan sebagai alat untuk mereduksi dimensi data, menjadi bentuk yang berada pada bidang nilai yang berbeda. Metode ini bekerja dengan cara menghitung covariance matrix dari data, dan kemudian mencari eigenvectors, dan eigenvalues [13]

\section{E. Segmentasi}

Segmentasi citra adalah sebuah proses untuk memisahkan sebuah objek dari background, sehingga objek tersebut dapat diproses untuk keperluan lain. Dengan proses segmentasi tersebut, masing-masing objek pada gambar dapat diambil secara individu sehingga dapat digunakan sebagai input bagi proses yang lain, sebagai contoh, pada proses rekontruksi objek 3 dimensi, diperlukan proses segmentasi untuk memisahkan objek yang akan direkontruksi terhadap background yang ada[14]

\section{F. Ekstrasi Ciri}

Ekstraksi ciri merupakan tahapan yang dilakukan untuk memperoleh ciri atau informasi tertentu dari suatu objek. Informasi yang didapat dari suatu objek dapat digunakan untuk mengenali objek serupa maupun untuk membedakan dengan objek lainnya. Contoh penggunaan ekstraksi ciri adalah untuk mengukur luas suatu objek[15]

\section{G. Pengolahan Warna RGB}

Model warna RGB merupakan model warna yang terdiri dari 3 komponen warna primer yaitu Red, Green, Blue. Dalam satu warna terdapat tida komponen warna yang jika digabungkan akan menjadi satu warna baru[16]

\section{H. Model Warna Hue Saturation Value}

HSV merupakan definisi dari hue, saturation, value. Hue merupakan ukuran dari jenis warna yang ada, sedangkan saturation merupakan keberwarnaannya dimana semakin berwarna semakin besar nilai saturasinya, namun semakin pudar berarti semakin rendah nilai saturasinya, dan value merupakan nilai kecerahan dari suatu warna [17]

\section{Metodologi Penelitian}

\section{A. Tahapan Penelitian}

Penelitian ini diawali dengan serangkaian tahapan umum dalam penelitian yang terdiri dari tahapan studi literatur untuk dijadikan referensi atau rujukan dalam penelitian kali ini guna memperkuat permasalahan serta sebagai dasar teori dalam melakukan penelitian. Studi literatur didapatkan dari membaca jurnal, artikel dan situs-situs di internet sehingga mendapatkan kumpulan referensi yang relefan dengan masalah dalam penelitian ini. Setelah melakukan studi literatur, peneliti melakukan identifikasi masalah yang akan di teliti untuk menjadi objek penelitian.

Selanjutnya peneliti melakukan proses pengumpulan data, proses pengumpulan data pada penelitian ini menggunakan data set public. Dataset public yang dilakukan adalah dengan mengunduh (download) gambar terkait dari google yaitu berupa gambar citra buah kopi yang ada pada variabel penelitian ini. Selanjutnya penelitian melakukan tahap pembuatan data set yaitu dengan melakukan preprocessing dimana tahapan yang di lakukan pada preprocessing kali ini adalah mengubah ukuran citra menjadi 500x500 pixel, mengubah warna background, dan mengubah jenis file citra menjadi JPG. Dari 135 data citra, hasil dari preprocessing tersebut terdapat 2 data yaitu data latih atau data training dan data uji atau data testing. Dimana terdapat sebanyak 90 data citra untuk data latih dan 45 data citra untuk data uji dan dikategorikan menjadi 3 kelas yaitu mentah, cukup matang dan matang.

Setelah mendapatkan data citra buah kopi yang akan di uji selanjutnya peneliti membuat sistem yang akan digunakan untuk mengklasifikasikan kematangan buah kopi berdasarkan deteksi warna. Sistem di buat menggunakan software berupa MATLAB dengan menggunakan metode Principal Component Analysis (PCA) untuk mengetahui sebaran data dan menggunakan metode $K$-Nearest Neighbor (K-NN) untuk melakukan klasifikasi dataset. Setelah sistem di buat maka selanjutnya dilakukan pengujian sistem untuk mengetahui tingkat keberhasilan dari sistem yang telah di buat. Hasil pengujian tersebut berupa sistem berfungsi dengan baik dan juga tingkat akurasi klasifikasi dari sistem yang sudah di buat.

Tahapan terakhir yaitu kesimpulan yang berisi rangkuman dari hasil pengujian sistem, dan rangkuman dari hasil akhir dari penelitian yang di lakukan, bisa berupa keakurasian dari sistem klasifikasi yang sudah kita buat serta hasil akurasi dari metodelogi yang di gunakan.

\section{B. Tahapan Pembuatan Sistem}

Sistem pada penelitian kali ini di buat menggunakan MATLAB. MATLAB merupakan sistem interaktif yang mempunyai data didalam suatu array sehingga pengguna 
tidak lagi disulitkan dengan masalah dimensi[14]. Pada perancangan sistem menggunakan MATLAB, dilakukan 3 tahapan yaitu tahapan pelatihan, tahapan pengujian dan pembuatan GUI. Pada tahapan pelatihan berisi membaca citra data training, segmentasi citra menggunakan thresholding otsu, menyempurnakan hasil segmentasi dengan melakukan operasi morfologi, ekstraksi ciri warna (RGB dan HSV) dan ciri ukuran (nilai area), mengkonversi hasil ekstraksi ciri menjadi principal component, mereduksi menjadi 2 principal component, dan plotting sebaran data pada masing masing kelas. Pada tahap pengujian flowchart berisi membaca citra data testing, segmentasi citra menggunakan thresholding otsu, menyempurnakan hasil segmentasi dengan melakukan operasi morfologi, ekstraksi ciri warna (RGB dan HSV) dan ciri ukuran (nilai area), mengkonversi hasil ekstraksi ciri menjadi principal component, mereduksi menjadi 2 principal component, melakukan klasifikasi berdasarkan tetangga terdekat, dan plotting sebaran data pada masing masing kelas. Pada pembuatan GUI di buat seperti gambar berikut ini :

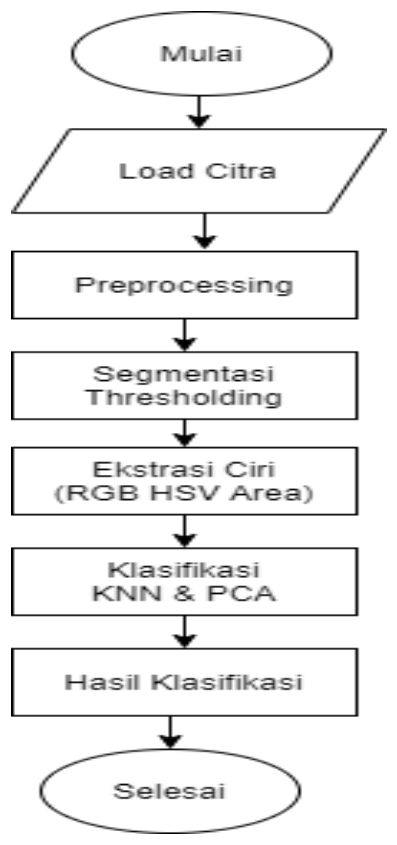

Gambar 1. Tahapan Pembuatan Sistem

Pada Gambar 1. Merupakan flowchart diagram tahapan pembuatan sistem yang akan dibuat untuk melakukan klasifikasi tingkat kematangan buah kopi. Tahapan awal yang dilakukan adalah load citra / input citra yaitu memasukan citra buah kopi ke dalam program dengan ukuran 500x500 piksel . selanjutnya masuk ketahap preprocessing, yaitu citra diubah menjadi citra greyscale dan di konversikan menjadi citra biner. Selanjutnya dilakukan segmentasi thresholding untuk memisahkan objek dengan background (latar belakang). Setelah objek dan background sudah terpisah tahapan selanjutnya adalah untuk menghitung hasil dari ekstrasi ciri Red Gren Blue (RGB), Hue Saturation Value (HSV) dan Area dari citra yang sudah disegmentasi. Hasil ektrasi ciri selanjutkan akan di klasifikasikan menggunakan KNN dan PCA, dan di dapatkan hasil klasifikasi tingkat kematangan buah kopi menggunakan metode KNN dan PCA.

K-Nearest Neighbor (KNN) merupakan sebuah metode untuk melakukan klasifikasi terhadap objek berdasarkan data pembelajaran yang jaraknya paling dekat dengan objek tersebut[12].Nilai jarak pada metode K-NN dapat di hitung dengan menggunakan rumus Euclidian Distance [18].Cara ini sederhana dan dapat memberikan akurasi yang baik terhadap hasil klasifikasi. Adapun rumus Euclidian Distance seperti pada rumus dibawah ini:

$$
d(x y)=\sqrt{\sum_{i=1}^{n}\left(x_{i}-y_{i}\right)^{2}}
$$

Keterangan:

$$
\begin{aligned}
& \mathrm{d}: \text { jarak kedekatan } \\
& \mathrm{x}: \text { data training } \\
& \mathrm{y}: \text { data testing } \\
& \mathrm{n}: \text { jumlah atribut antara } 1 \mathrm{s.d} \mathrm{n} \\
& \mathrm{i}: \text { atribut individu antara } 1 \mathrm{s.d} \mathrm{n}
\end{aligned}
$$

\section{HASIL DAN PEMBAHASAN}

Pada penelitian ini peneliti membuat sebuah sistem untuk klasifikasi tingkat kematangan buah kopi. Adapun dalam penelitian kali ini menggunakan algoritma $K$-Nearest Neighbor untuk mengklasifikasi data dan menggunakan algoritma Principal Component Analysis untuk mendapatkan sebaran dari dataset. Untuk mempermudah dalam penelitian kali ini, peneliti menggunakan pemrograman MATLAB R2019b untuk pembuatan sistem klasifikasi kematangan buah kopi. Tingkat kematangan buah kopi yang di gunakan adalah buah kopi Mentah, buah kopi cukup matang, dan buah kopi Matang. Berikut contoh tingkat kematangan buah kopi yang di gunakan dalam penelitian kali ini:

TABEL I

TABEL KELAS BUAH KOPI

\begin{tabular}{|c|c|c|c|}
\hline No. & Kelas & Definisi & Gambar \\
\hline 1. & Mentah & $\begin{array}{c}\text { Citra berupa buah kopi } \\
\text { mentah }\end{array}$ & \\
\hline 2. & Cukup Matang & $\begin{array}{c}\text { Citra berupa buah kopi } \\
\text { cukup matang }\end{array}$ & \\
\hline 3. & Matang & $\begin{array}{r}\text { Citra berupa buah kopi } \\
\text { matang }\end{array}$ & \\
\hline
\end{tabular}

\section{A. Pembuatan Sistem}

Dalam pembuatan sistem dilakukan 3 tahap yaitu tahap pelatihan yang bertujuan melakukan klasifikasi dari data latih yang ada, tahap pengujian yang bertujuan mengklasifikasikan data uji berdasarkan data latih yang ada, tahap terakhir yaitu pembuatan GUI dari sistem klasifikasi kematangan buah kopi. 
1) Tahap Pelatihan: Pada tahapan pelatihan menggunakan aplikasi MATLAB, dilakukan dengan menggunakan 90 data citra latih buah kopi dan dibagi menjadi 3 kelas yaitu, mentah, cukup matang dan matang. 90 citra tersebut dilakukan ekstraksi ciri RGB, HSV, dan Area. selanjutnya dikonversi menjadi principal component yang berikutnya direduksi menjadi 2PC. Hasil tersebut selanjutnya divisualisasikan menggunakan algoritma Principal Component Analysis untuk memudahkan dalam mengetahui sebaran data dari masing masing citra agar nantinya memudahkan dalam klasifikasi menggunakan KNN Sebaran data dari 90 citra data latih dapat dilihat pada Gambar 2. Sebagai tambahan ialah titik berwarna merah adalah sebaran data dari kelas cukup matang, titik berwarna hijau adalah sebaran data dari kelas matang, dan titik berwarna biru adalah sebaran dari data dari kelas mentah :

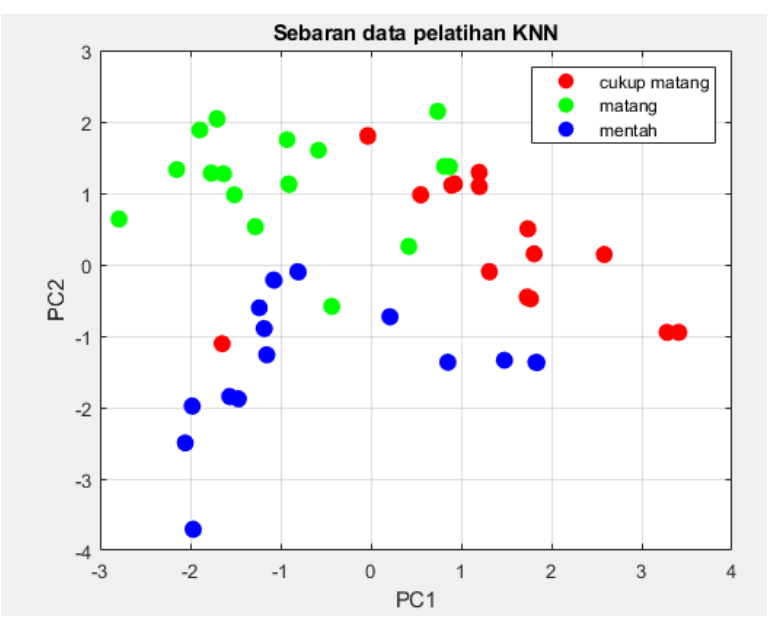

Gambar 2. Grafik sebaran data latih

2) Tahap Pengujian : Berikutnya dilakukan pengujian menggunakan 45 citra buah kopi dengan tingkat kematangan berbeda. Pada tahap pengujian langkah yang dilakukan sama seperti pada tahap pelatihan. Bedanya pada tahap pengujian, data uji diuji menggunakan metode KNN berdasarkan dari banyaknya tetangga terdekat yang didapatkan dari tahap pelatihan. Dari tahap pengujian didapatkan sebaran dari 45 data uji yang divisualisasikan menggunakan algoritma PCA. Sebaran data uji terhadap data latih tersebut dapat dilihat pada Gambar 3. Sebagai tambahan, tanda silang (x) memiliki 3 warna untuk 3 kelas yaitu, warna biru muda untuk data uji dengan kelas cukup matang, warna ungu untuk data uji dengan kelas matang, dan warna kuning untuk data uji dengan kelas mentah.

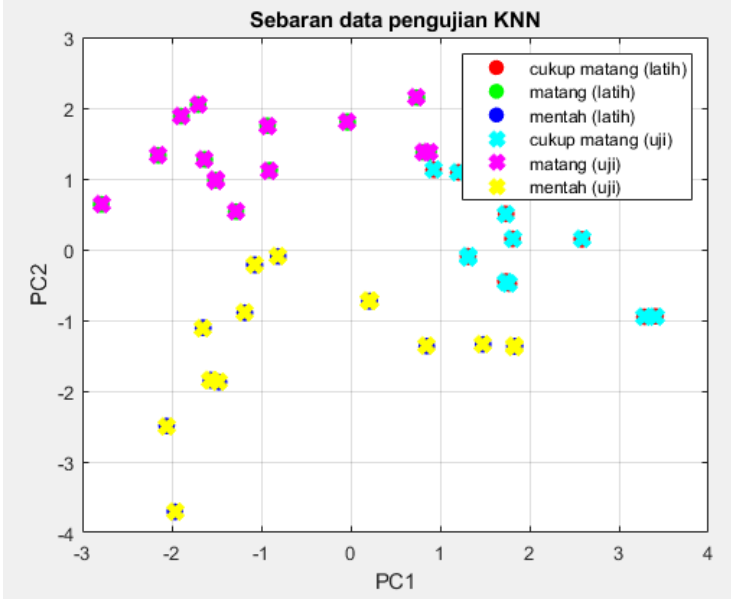

\section{Gambar 3. Grafik sebaran data uji}

3) Pembuatan GUI : GUI pada sistem klasifikasi kematangan buah kopi di buat menggunakan software MATLAB R2019b. Pada sistem yang di buat kali ini memiliki beberapa fungsi yaitu load citra/input citra, segmentasi, ekstraksi ciri, klasifikasi, dan reset. Load citra/input citra berfungsi untuk memilih citra yang akan ditampilkan pada sistem. Segmentasi berfungsi untuk nampilkan hasil segmentasi dari citra yang sudah di pilih tadi, untuk menyempurnakan hasil segmentasi dilakukan pula operasi morfologi pada sistem ini. Ektraksi ciri berfungsi untuk menampilkan hasil dari ekstraksi ciri(RGB, HSV, dan Area) dari citra yang sudah di segmentasi. Klasifikasi berfungsi menampilkan hasil klasifikasi menggunakan metode KNN. Reset berfungsi mengatur ulang sistem. GUI dari sistem klasifikasi kematangan buah kopi dapat di lihat pada Gambar 4 berikut ini:

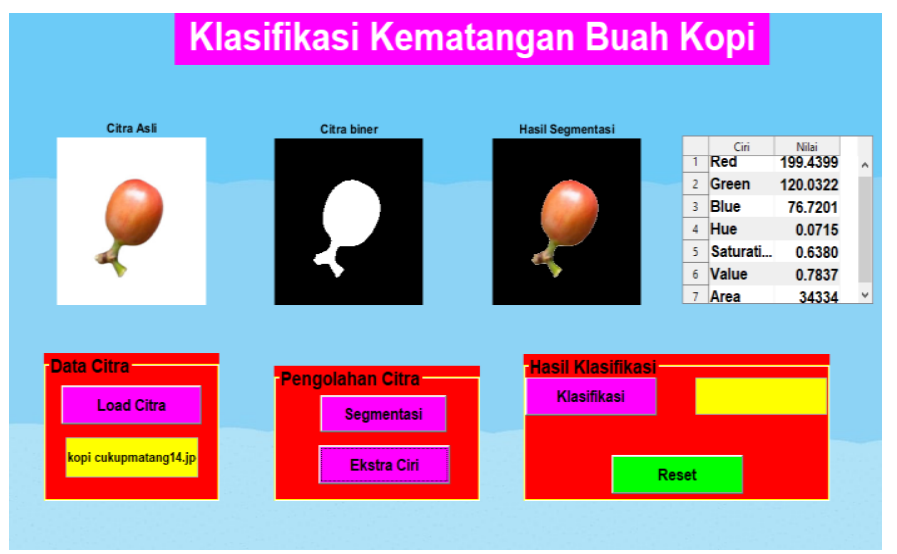

Gambar 4. GUI Sistem

\section{B. Implementasi}

Penelitian ini mengimplementasikan metode $K$-Nearest Neighbor dalam melakukan klasifikasi data. Adapun dalam implementasi metode KNN dengan cara mengukur jarak terdekat antara data uji ke data latih. Dalam penelitian ini terdapat label dan atribut, label yang di ambil dari tingkat kematangan buah dan atribut yang didapat dari hasil ekstraksi ciri citra. Atribut tersebut yaitu $\mathrm{R}($ red $), \mathrm{G}($ green $), \mathrm{B}($ blue $)$, $\mathrm{H}($ hue), $\mathrm{S}$ (saturation), V(value), dan Area. Pada tahap ini di lakukan perhitungan nilai ekstrasi ciri data latih, pada table 2 di tampilkan sebanyak 30 data dari total keseluruhan data sebanyak 90 data citra latih:

TABEL II

TABEL EKSTRASI CIRI DATA LATIH

$\begin{array}{ccccccccc}\text { No } & \mathbf{8} & \mathbf{G} & \mathbf{B} & \mathbf{H} & \mathbf{S} & \mathbf{V} & \text { Area } & \text { Label } \\ & 214,5 & 196,7 & 113,9 & 0,141 & 0,488 & 0,846 & 88166 & \text { Cukup } \\ \mathbf{1} & 255 & 355 & 799 & 8 & 9 & 1 & & \text { Matang } \\ & 198,1 & 127,6 & 88,39 & 0,062 & 0,581 & 0,777 & 46811 & \text { Cukup } \\ \mathbf{2} & 734 & 697 & 01 & 6 & 1 & 2 & & \text { Matang }\end{array}$




\begin{tabular}{|c|c|c|c|c|c|c|c|c|}
\hline 3 & $\begin{array}{c}227,2 \\
522\end{array}$ & $\begin{array}{c}127,5 \\
474\end{array}$ & $\begin{array}{c}116,4 \\
9\end{array}$ & $\begin{array}{c}0,384 \\
4\end{array}$ & $\begin{array}{c}0,534 \\
3\end{array}$ & $\begin{array}{c}0,891 \\
2\end{array}$ & 34758 & $\begin{array}{l}\text { Cukup } \\
\text { Matang }\end{array}$ \\
\hline 4 & $\begin{array}{c}214,4 \\
647\end{array}$ & $\begin{array}{c}196,8 \\
267\end{array}$ & $\begin{array}{c}114,3 \\
783\end{array}$ & $\begin{array}{c}0,142 \\
2\end{array}$ & $\begin{array}{c}0,486 \\
7\end{array}$ & $\begin{array}{c}0,845 \\
6\end{array}$ & 64281 & $\begin{array}{l}\text { Cukup } \\
\text { Matang }\end{array}$ \\
\hline 5 & $\begin{array}{c}211,9 \\
491\end{array}$ & $\begin{array}{c}124,6 \\
345\end{array}$ & $\begin{array}{c}38,79 \\
04\end{array}$ & $\begin{array}{c}0,082 \\
5\end{array}$ & $\begin{array}{c}0,816 \\
8\end{array}$ & $\begin{array}{c}0,831 \\
3\end{array}$ & 27517 & $\begin{array}{l}\text { Cukup } \\
\text { Matang }\end{array}$ \\
\hline 6 & $\begin{array}{c}229,4 \\
47\end{array}$ & $\begin{array}{c}134,7 \\
122\end{array}$ & $\begin{array}{c}48,50 \\
49\end{array}$ & $\begin{array}{c}0,077 \\
8\end{array}$ & $\begin{array}{c}0,789 \\
9\end{array}$ & $\begin{array}{c}0,899 \\
8\end{array}$ & 28677 & $\begin{array}{l}\text { Cukup } \\
\text { Matang }\end{array}$ \\
\hline 7 & $\begin{array}{c}221,2 \\
699\end{array}$ & $\begin{array}{c}137,2 \\
557\end{array}$ & $\begin{array}{c}37,50 \\
98\end{array}$ & $\begin{array}{c}0,089 \\
9\end{array}$ & $\begin{array}{c}0,829 \\
4\end{array}$ & $\begin{array}{c}0,867 \\
7\end{array}$ & 52431 & $\begin{array}{l}\text { Cukup } \\
\text { Matang }\end{array}$ \\
\hline 8 & $\begin{array}{c}233,3 \\
038\end{array}$ & $\begin{array}{c}105,3 \\
619\end{array}$ & $\begin{array}{c}50,70 \\
33\end{array}$ & $\begin{array}{c}0,050 \\
8\end{array}$ & $\begin{array}{c}0,787 \\
1\end{array}$ & $\begin{array}{c}0,914 \\
9\end{array}$ & 44961 & $\begin{array}{l}\text { Cukup } \\
\text { Matang }\end{array}$ \\
\hline 9 & $\begin{array}{c}198,0 \\
41\end{array}$ & $\begin{array}{c}128,2 \\
203\end{array}$ & $\begin{array}{c}88,76 \\
26\end{array}$ & $\begin{array}{c}0,061 \\
3\end{array}$ & 0,578 & $\begin{array}{c}0,776 \\
6\end{array}$ & 50668 & $\begin{array}{l}\text { Cukup } \\
\text { Matang }\end{array}$ \\
\hline 10 & $\begin{array}{c}222,1 \\
152\end{array}$ & $\begin{array}{c}55,42 \\
756\end{array}$ & $\begin{array}{c}29,81 \\
91\end{array}$ & $\begin{array}{c}0,062 \\
5\end{array}$ & $\begin{array}{c}0,869 \\
5\end{array}$ & 0,871 & 28213 & $\begin{array}{l}\text { Cukup } \\
\text { Matang }\end{array}$ \\
\hline 11 & $\begin{array}{c}146,4 \\
502\end{array}$ & $\begin{array}{c}24,38 \\
35\end{array}$ & $\begin{array}{c}33,47 \\
54\end{array}$ & $\begin{array}{c}0,831 \\
4\end{array}$ & $\begin{array}{c}0,865 \\
4\end{array}$ & $\begin{array}{c}0,574 \\
3\end{array}$ & 37512 & Matang \\
\hline 12 & $\begin{array}{c}111,7 \\
966\end{array}$ & $\begin{array}{c}23,54 \\
27\end{array}$ & $\begin{array}{c}33,14 \\
05\end{array}$ & $\begin{array}{c}0,888 \\
9\end{array}$ & $\begin{array}{c}0,839 \\
6\end{array}$ & $\begin{array}{c}0,438 \\
4\end{array}$ & 44473 & Matang \\
\hline 13 & $\begin{array}{c}149,1 \\
216\end{array}$ & $\begin{array}{c}61,15 \\
44\end{array}$ & $\begin{array}{c}52,40 \\
23\end{array}$ & $\begin{array}{c}0,055 \\
4\end{array}$ & $\begin{array}{c}0,649 \\
8\end{array}$ & $\begin{array}{c}0,584 \\
8\end{array}$ & 60346 & Matang \\
\hline 14 & $\begin{array}{c}150,5 \\
066\end{array}$ & $\begin{array}{c}43,18 \\
71\end{array}$ & $\begin{array}{c}35,91 \\
94\end{array}$ & $\begin{array}{c}0,386 \\
6\end{array}$ & $\begin{array}{c}0,794 \\
9\end{array}$ & $\begin{array}{c}0,590 \\
3\end{array}$ & 67267 & Matang \\
\hline 15 & $\begin{array}{c}206,1 \\
835\end{array}$ & $\begin{array}{c}67,35 \\
41\end{array}$ & $\begin{array}{c}88,61 \\
48\end{array}$ & $\begin{array}{c}0,932 \\
6\end{array}$ & $\begin{array}{c}0,688 \\
7\end{array}$ & $\begin{array}{c}0,808 \\
6\end{array}$ & 89808 & Matang \\
\hline 16 & $\begin{array}{c}147,2 \\
641\end{array}$ & $\begin{array}{c}28,95 \\
69\end{array}$ & $\begin{array}{c}52,46 \\
86\end{array}$ & $\begin{array}{c}0,940 \\
5\end{array}$ & $\begin{array}{c}0,846 \\
6\end{array}$ & $\begin{array}{c}0,577 \\
5\end{array}$ & 42269 & Matang \\
\hline 17 & $\begin{array}{c}145,9 \\
795\end{array}$ & $\begin{array}{c}38,16 \\
23\end{array}$ & $\begin{array}{c}57,71 \\
76\end{array}$ & $\begin{array}{c}0,948 \\
8\end{array}$ & $\begin{array}{c}0,793 \\
6\end{array}$ & $\begin{array}{c}0,572 \\
5\end{array}$ & 47673 & Matang \\
\hline 18 & $\begin{array}{c}147,0 \\
838\end{array}$ & $\begin{array}{c}28,83 \\
28\end{array}$ & $\begin{array}{c}52,34 \\
01\end{array}$ & $\begin{array}{c}0,941 \\
4\end{array}$ & $\begin{array}{c}0,847 \\
2\end{array}$ & $\begin{array}{c}0,576 \\
8\end{array}$ & 67019 & Matang \\
\hline 19 & $\begin{array}{c}177,4 \\
723\end{array}$ & $\begin{array}{c}46,38 \\
14\end{array}$ & $\begin{array}{c}26,01 \\
99\end{array}$ & $\begin{array}{c}0,127 \\
8\end{array}$ & $\begin{array}{c}0,880 \\
6\end{array}$ & $\begin{array}{c}0,696 \\
2\end{array}$ & 60979 & Matang \\
\hline 20 & $\begin{array}{c}206,3 \\
027\end{array}$ & $\begin{array}{c}67,33 \\
17\end{array}$ & $\begin{array}{c}88,54 \\
97\end{array}$ & $\begin{array}{c}0,932 \\
1\end{array}$ & $\begin{array}{c}0,689 \\
1\end{array}$ & 0,809 & 79915 & Matang \\
\hline 21 & $\begin{array}{c}105,0 \\
995\end{array}$ & $\begin{array}{c}188,6 \\
297\end{array}$ & $\begin{array}{c}76,67 \\
77\end{array}$ & $\begin{array}{c}0,294 \\
6\end{array}$ & $\begin{array}{c}0,623 \\
7\end{array}$ & $\begin{array}{c}0,739 \\
7\end{array}$ & 41717 & Mentah \\
\hline 22 & $\begin{array}{c}128,9 \\
803\end{array}$ & $\begin{array}{c}197,2 \\
611\end{array}$ & $\begin{array}{c}88,13 \\
02\end{array}$ & $\begin{array}{c}0,276 \\
3\end{array}$ & $\begin{array}{c}0,579 \\
9\end{array}$ & $\begin{array}{c}0,773 \\
6\end{array}$ & 36577 & Mentah \\
\hline 23 & $\begin{array}{c}120,1 \\
061\end{array}$ & $\begin{array}{c}187,7 \\
377\end{array}$ & $\begin{array}{c}52,85 \\
84\end{array}$ & $\begin{array}{c}0,250 \\
6\end{array}$ & $\begin{array}{c}0,732 \\
9\end{array}$ & $\begin{array}{c}0,736 \\
2\end{array}$ & 12955 & Mentah \\
\hline 24 & $\begin{array}{c}156,2 \\
676\end{array}$ & $\begin{array}{c}183,8 \\
812\end{array}$ & $\begin{array}{c}89,35 \\
06\end{array}$ & 0,215 & $\begin{array}{c}0,537 \\
2\end{array}$ & $\begin{array}{c}0,721 \\
3\end{array}$ & 78831 & Mentah \\
\hline 25 & $\begin{array}{c}90,27 \\
39\end{array}$ & $\begin{array}{c}99,78 \\
61\end{array}$ & $\begin{array}{c}41,85 \\
72\end{array}$ & $\begin{array}{c}0,194 \\
1\end{array}$ & $\begin{array}{c}0,598 \\
5\end{array}$ & $\begin{array}{c}0,393 \\
2\end{array}$ & 24557 & Mentah \\
\hline 26 & $\begin{array}{c}75,86 \\
87\end{array}$ & $\begin{array}{c}90,83 \\
12\end{array}$ & $\begin{array}{c}37,30 \\
95\end{array}$ & $\begin{array}{c}0,218 \\
1\end{array}$ & $\begin{array}{c}0,596 \\
9\end{array}$ & $\begin{array}{c}0,357 \\
7\end{array}$ & 19877 & Mentah \\
\hline 27 & $\begin{array}{c}87,73 \\
51\end{array}$ & $\begin{array}{c}104,4 \\
947\end{array}$ & $\begin{array}{c}43,74 \\
36\end{array}$ & $\begin{array}{c}0,214 \\
8\end{array}$ & $\begin{array}{c}0,591 \\
1\end{array}$ & $\begin{array}{c}0,409 \\
9\end{array}$ & 24208 & Mentah \\
\hline 28 & $\begin{array}{c}137,3 \\
926\end{array}$ & $\begin{array}{c}140,2 \\
325\end{array}$ & $\begin{array}{c}23,80 \\
2\end{array}$ & $\begin{array}{c}0,170 \\
7\end{array}$ & $\begin{array}{c}0,845 \\
4\end{array}$ & $\begin{array}{c}0,557 \\
7\end{array}$ & 30190 & Mentah \\
\hline 29 & $\begin{array}{c}146,8 \\
833\end{array}$ & $\begin{array}{c}150,4 \\
129\end{array}$ & $\begin{array}{c}25,62 \\
28\end{array}$ & $\begin{array}{c}0,171 \\
8\end{array}$ & $\begin{array}{c}0,847 \\
4\end{array}$ & $\begin{array}{c}0,592 \\
4\end{array}$ & 27007 & Mentah \\
\hline 30 & $\begin{array}{c}156,8 \\
371\end{array}$ & $\begin{array}{c}184,3 \\
725\end{array}$ & $\begin{array}{c}90,00 \\
68\end{array}$ & 0,215 & $\begin{array}{c}0,534 \\
1\end{array}$ & $\begin{array}{c}0,723 \\
2\end{array}$ & 72434 & Mentah \\
\hline
\end{tabular}

Selanjutnya akan dihitung jarak terdekat dari data uji terhadap 90 data latih. Sebagai contoh peneliti mengambil 1 data uji untuk dilakukan perhitungan menggunakan rumus Euclidean Distance. Yang mana ekstraksi data uji sebagai berikut

TABEL III

EKSTRAKSI CIRI DATA UJI 1

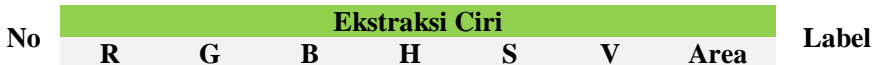

$\begin{array}{ccccccccc}1 & 214,5 & 196,7 & 113,9 & 0,141 & 0,488 & 0,846 & 88166 & ?\end{array}$

Dari hasil perhitungan ekstraksi ciri pada Tabel 2 dan Tabel 3 maka dapat dilakukan pengklasifikasian menggunakan KNN dengan menghitung jarak terdekat dengan rumus Euclidean Distance. Perhitungan menggunakan Euclidean Distance adalah sebagai berikut:

$$
d=\sqrt{\begin{array}{c}
\left(R_{\text {latih }}-R_{\text {ujp }}\right)^{2}+\left(G_{\text {latih }}-G_{\text {uji }}\right)^{2}+\left(B_{\text {latih }}-B_{\text {uji }}\right)^{2}+\left(H_{\text {latih }}-H_{\text {uji }}\right)^{2} \\
+\left(S_{\text {latih }}-S_{\text {uji }}\right)^{2}+\left(V_{\text {latih }}-V_{\text {uji }}\right)^{2}+\left(\text { Area }_{\text {latih }}-\text { Area }_{\text {uji }}\right)^{2}
\end{array}}
$$

Dari perhitungan diatas didapatkan hasil pengujian data uji terhadap data latih, pada tabel 4 di tampilkan sebanyak 30 data dari total keseluruhan data sebanyak 90 data seperti pada Tabel 4 berikut ini.

TABEL IV

Euclidean Distance Data uji 1 terhadap 90 Data latih

\begin{tabular}{|c|c|c|}
\hline No & Keterangan & $\begin{array}{c}\text { Euclidean } \\
\text { Distance }\end{array}$ \\
\hline 1 & Data uji 1 terhadap Data latih 1 & 0,000 \\
\hline 2 & Data uji 1 terhadap Data latih 2 & 0,820 \\
\hline 3 & Data uji 1 terhadap Data latih 3 & 0,910 \\
\hline 4 & Data uji 1 terhadap Data latih 4 & 0,328 \\
\hline 5 & Data uji 1 terhadap Data latih 5 & 1,536 \\
\hline 6 & Data uji 1 terhadap Data latih 6 & 1,419 \\
\hline 7 & Data uji 1 terhadap Data latih 7 & 1,391 \\
\hline 8 & Data uji 1 terhadap Data latih 8 & 1,350 \\
\hline 9 & Data uji 1 terhadap Data latih 9 & 0,779 \\
\hline 10 & Data uji 1 terhadap Data latih 10 & 1,814 \\
\hline 11 & Data uji 1 terhadap Data latih 31 & 2,157 \\
\hline 12 & Data uji 1 terhadap Data latih 32 & 2,294 \\
\hline 13 & Data uji 1 terhadap Data latih 33 & 1,406 \\
\hline 14 & Data uji 1 terhadap Data latih 34 & 1,708 \\
\hline 15 & Data uji 1 terhadap Data latih 35 & 1,399 \\
\hline 16 & Data uji 1 terhadap Data latih 36 & 2,077 \\
\hline 17 & Data uji 1 terhadap Data latih 37 & 1,961 \\
\hline 18 & Data uji 1 terhadap Data latih 38 & 2,003 \\
\hline 19 & Data uji 1 terhadap Data latih 39 & 1,772 \\
\hline 20 & Data uji 1 terhadap Data latih 40 & 1,403 \\
\hline 21 & Data uji 1 terhadap Data latih 61 & 1,231 \\
\hline 22 & Data uji 1 terhadap Data latih 62 & 1,065 \\
\hline 23 & Data uji 1 terhadap Data latih 63 & 1,603 \\
\hline 24 & Data uji 1 terhadap Data latih 54 & 0,625 \\
\hline 25 & Data uji 1 terhadap Data latih 65 & 1,891 \\
\hline 26 & Data uji 1 terhadap Data latih 66 & 2,050 \\
\hline 27 & Data uji 1 terhadap Data latih 67 & 1,869 \\
\hline 28 & Data uji 1 terhadap Data latih 68 & 1,835 \\
\hline 29 & Data uji 1 terhadap Data latih 69 & 1,793 \\
\hline 30 & Data uji 1 terhadap Data latih 70 & 0,639 \\
\hline
\end{tabular}

Dari perhitungan tersebut dilakukan klasifikasi dengan nilai $\mathrm{K}=3$, hasil klasifikasi tingkat kematangan buah kopi dari data uji 1 yaitu Cukup Matang. Proses diatas diulang sebanyak jumlah data uji yaitu 45 data uji sehingga didapatkan hasil sebagai berikut : 
TABEL V

Hasil Pengujian Data uji

\begin{tabular}{|c|c|c|c|}
\hline Data uji & Kelas Asli & Hasil KNN & Keterangan \\
\hline 1 & Cukup Matang & Cukup Matang & Akurat \\
\hline 2 & Cukup Matang & Cukup Matang & Akurat \\
\hline 3 & Cukup Matang & Cukup Matang & Akurat \\
\hline 4 & Cukup Matang & Cukup Matang & Akurat \\
\hline 5 & Cukup Matang & Cukup Matang & Akurat \\
\hline 6 & Cukup Matang & Cukup Matang & Akurat \\
\hline 7 & Cukup Matang & Cukup Matang & Akurat \\
\hline 8 & Cukup Matang & Cukup Matang & Akurat \\
\hline 9 & Cukup Matang & Cukup Matang & Akurat \\
\hline 10 & Cukup Matang & Cukup Matang & Akurat \\
\hline 11 & Cukup Matang & Cukup Matang & Akurat \\
\hline 12 & Cukup Matang & Cukup Matang & Akurat \\
\hline 13 & Cukup Matang & Cukup Matang & Akurat \\
\hline 14 & Cukup Matang & Cukup Matang & Akurat \\
\hline 15 & Cukup Matang & Cukup Matang & Akurat \\
\hline 16 & Matang & Matang & Akurat \\
\hline 17 & Matang & Matang & Akurat \\
\hline 18 & Matang & Matang & Akurat \\
\hline 19 & Matang & Matang & Akurat \\
\hline 20 & Matang & Matang & Akurat \\
\hline 21 & Matang & Matang & Akurat \\
\hline 22 & Matang & Matang & Akurat \\
\hline 23 & Matang & Matang & Akurat \\
\hline 24 & Matang & Matang & Akurat \\
\hline 25 & Matang & Matang & Akurat \\
\hline 26 & Matang & Matang & Akurat \\
\hline 27 & Matang & Matang & Akurat \\
\hline 28 & Matang & Matang & Akurat \\
\hline 29 & Matang & Matang & Akurat \\
\hline 30 & Matang & Matang & Akurat \\
\hline 31 & Mentah & Mentah & Akurat \\
\hline 32 & Mentah & Mentah & Akurat \\
\hline 33 & Mentah & Matang & Tidak Akurat \\
\hline 34 & Mentah & Mentah & Akurat \\
\hline 35 & Mentah & Mentah & Akurat \\
\hline 36 & Mentah & Mentah & Akurat \\
\hline 37 & Mentah & Mentah & Akurat \\
\hline 38 & Mentah & Mentah & Akurat \\
\hline 39 & Mentah & Mentah & Akurat \\
\hline 40 & Mentah & Mentah & Akurat \\
\hline 41 & Mentah & Mentah & Akurat \\
\hline
\end{tabular}

$\begin{array}{llll}42 & \text { Mentah } & \text { Mentah } & \text { Akurat } \\ 43 & \text { Mentah } & \text { Mentah } & \text { Akurat } \\ 44 & \text { Mentah } & \text { Mentah } & \text { Akurat } \\ 45 & \text { Mentah } & \text { Mentah } & \text { Akurat }\end{array}$

Dari 45 data uji yang dihitung menggunakan metode KNN didapatkan sebanyak 45 citra dengan hasil klasifikasi akurat dan 1 citra dengan hasil klasifikasi tidak akurat dan dapat diketahui dari hasil pengujian yaitu dirumuskan sebagai berikut:

Akurasi $=\frac{\text { Jumlah Data Benar }}{\text { Jumlah Seluruh Data }} \times 100 \%$

Maka mendapatkan tingkat akurasi sebagai berikut :

Akurasi $=\frac{44}{45} \times 100 \%=97,77 \%$

Tingkat Akurasi yang diperoleh pada sistem klasifikasi tingkat kematangan buah kopi dengan metode K-Nearest Neighbor (KNN) adalah $97,7 \%$ dari 45 Data uji dengan nilai $\mathrm{K}=3$, dengan diagram akurasi sebagai berikut:

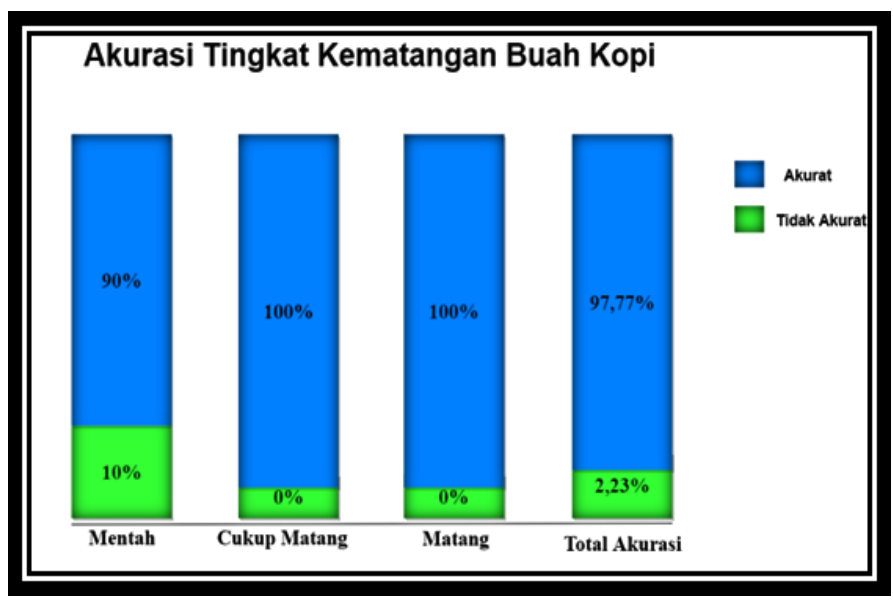

Gambar 4. Diagram Akurasi

\section{KESIMPULAN}

Dari penilitan ini dihasilkan berupa sistem klasifikasi tingkat kematangan buah kopi yang di kembangkan menggunakan software MATLAB R2019b, dimana sistem tersebut dapat mengklasifikasikan tingkat kematangan buah kopi yaitu memanfaatkan citra dari buah kopi dengan menginput berupa gambar buah kopi yang sudah di preprocessing menjadi background berwarna putih agar mudah dalam proses segmentasi. Sistem klasifikasi tingkat kematangan buah kopi menggunakan metode $K$-Nearest Neighbor untuk mengklasifikasikan tingkat kematangan buah kopi dengan memanfaatkan fitur warna RGB, HSV dan Area menggunakan 90 data latih citra buah kopi dan 45 data uji citra buah kopi dengan 3 kelas kematangan buah yaitu mentah, cukup matang, dan matang. Dari sistem tersebut didapatkan 
hasil akurasi dari klasifikasi tingkat kematangan buah kopi menggunakan metode $\mathrm{KNN}$ sebesar $97,77 \%$ dengan nilai $\mathrm{K}=3$ yang didapat dari 44 data uji dengan klasifikasi akurat, dan2,23\% dari 1 data uji dengan klasifikasi tidak akurat. Hasil dari penelitian ini diharapkan selain untuk membantu para petani kopi, terdapat juga pengklasifikasian buah kopi yang dijual ke masyarakat sehingga kualitas kopi yang diterima oleh masyarakat menjadi lebih baik berdasarkan tingkat kematanganya.

\section{UCAPAN TERIMA KASIH}

Penelitian ini dapat berjalan berkat bantuan dari Bapak Dadang Iskandar Mulyana selaku Ketua Program Studi Teknik Informatika Sekolah Tinggi Ilmu Komputer Cipta Karya Informatika dan juga selaku Dosen matakuliah Pengolahan Citra. Ucapan terimakasih juga peneliti sampaikan kepada Bapak Veri Arinal selaku Dosen Pembimbing selama dilakukan penelitian ini.

\section{REFERENSI}

[1] A. S. Eko Hari, "Pengukuran Tingkat Kematangan Kopi Robusta Menggunakan Algoritma K-Nearest Neighbor," Pros. SENDI_U 2018 , pp. 978-979, 2018

[2] M. Arief, "Klasifikasi Kematangan Buah Jeruk Berdasarkan Fitur Warna Menggunakan Metode SVM,” J. Ilmu Komput. dan Desain Komun. Vis., vol. 4, no. 1, pp. 9-16, 2019.

[3] C. Paramita, E. H. Rachmawanto, C. A. Sari, D. R. Ignatius, and M Setiadi, "Klasifikasi Jeruk Nipis Terhadap Tingkat Kematangan Buah Berdasarkan Fitur Warna Menggunakan K-Nearest Neighbor," vol. 04 no. 1, pp. 1-6, 2019, doi: 10.30591/jpit.v4i1.1267.

[4] A. Abdullah and P. Pahrianto, "Sistem Klasifikasi Kematangan Tomat Berdasarkan Warna Dan Bentuk Menggunakan Metode Support Vector Machine (SVM)," JSI J. Sist. Inf., vol. 9, no. 2, pp. 1313-1322, 2017, doi: $10.36706 /$ jsi.v9i2.5007.

[5] D. Novianto and T. Sugihartono, "Sistem Deteksi Kualitas Buah Jambu Air Berdasarkan Warna Kulit Menggunakan Algoritma Principal Component Analysis ( Pca ) dan K-Nearest Neigbor ( K-NN )," vol. 11, no. 2, pp. 42-47, 2020.

[6] D. I. Muhammad, E. Ermatita, and N. Falih, "Penggunaan K-Neares Neighbor (KNN) untuk Mengklasifikasi Citra Belimbing Berdasarkan Fitur Warna," Inform. J. Ilmu Komput., vol. 17, no. 1, p. 9, 2021, doi: 10.52958/iftk.v17i1.2132.

[7] D. R. Taningrum, B. Hidayat, and Y. S. Hariyani, "IDENTIFICATION SYSTEM LICENSE PLATE ON VEHICLES USING PRINCIPAL COMPONENT ANALYSIS AND K-NN CLASSIFICATION Classification," e-Proceeding Eng., vol. 3, no. 2, pp. 1868-1876, 2016.

[8] Y. E. Yana and N. Nafi'iyah, "Klasifikasi Jenis Pisang Berdasarkan Fitur Warna, Tekstur, Bentuk Citra Menggunakan SVM dan KNN," Res. J. Comput. Inf. Syst. Technol. Manag., vol. 4, no. 1, p. 28, 2021 doi: 10.25273/research.v4i1.6687.

[9] A. Sindar and R. M. Sinaga, "IMPLEMENTASI TEKNIK THRESHODING PADA SEGMENTASI CITRA DIGITAL," vol. 1, no. 2, pp. 48-51, 2017.

[10] P. Sari, L. Muflikah, and R. C. Wihandika, "Klasifikasi Kualitas Susu Sapi Menggunakan Metode Support Vector Machine ( SVM )," J. Pengemb. Teknol. Inf. dan Ilmu Komput., vol. 2, no. 3, pp. 1204-1211, 2018.

[11] A. Budi, S. Suma'inna, and H. Maulana, "Pengenalan Citra Wajah Sebagai Identifier Menggunakan Metode Principal Component Analysis (PCA)," J. Tek. Inform., vol. 9, no. 2, pp. 166-175, 2016, doi 10.15408/jti.v9i2.5608.

[12] I. M. B. S. I Made Ary Swantika, Bulkis Kanata, "Perancangan Sistem Untuk Mengetahui Kualitas Biji Kopi Berdasarkan Warna Dengan KNearest Neighbor," J. Bakti Nusa, vol. 1, no. 2, pp. 25-36, 2020.
[13] D. A. Nugraha and A. S. Wiguna, "Seleksi Fitur Warna Citra Digital Biji Kopi Menggunakan Metode Principal Component Analysis," Res. Comput. Inf. Syst. Technol. Manag., vol. 3, no. 1, p. 24, 2020, doi: 10.25273/research.v3i1.5352.

[14] L. Indriyani, W. Susanto, and D. Riana, "Aplikasi Matlab Pada Pengukuran Diameter buah Jeruk Keprok," IJCIT (Indonesian J. Comput. Inf. Technol., vol. 2, no. 1, pp. 46-52, 2017.

[15] D. Prasetyo, "Aplikasi Pendeteksi Jerawat Di Wajah Dengan Menggunakan Teknik Pengolahan Citra Pada Foto," 2018.

[16] L. Farokhah and P. Korespondensi, "Implementasi K-Nearest Neighbor Untuk Klasifikasi Bunga Dengan Ekstraksi Fitur Warna Rgb Implementation of K-Nearest Neighbor for Flower Classification With Extraction of Rgb Color Features," J. Teknol. Inf. dan Ilmu Komput., vol. 7, no. 6, pp. 1129-1136, 2020, doi: 10.25126/jtiik.202072608.

[17] C. Habib, M. Surudin, Y. Widiastiwi, and N. Chamidah, "Penerapan Algoritma K-Nearest Neighbor Pada Klasifikasi Kesegaran Citra Ayam Broiler Berdasarkan Warna Daging Dada Ayam," Senamika, pp. 799809, 2020.

[18] S. F. Kusuma, R. E. Pawening, and R. Dijaya, "Otomatisasi klasifikasi kematangan buah mengkudu berdasarkan warna dan tekstur," Regist. J. Ilm. Teknol. Sist. Inf., vol. 3, no. 1, p. 17, 2017, doi: 10.26594/r.v3i1.576. 